\title{
A Comparison of Stress Susceptibility of Sea Urchins and Sea Cucumbers in Aquaculture Conditions
}

\author{
Regina Shannon, Ahmed Mustafa \\ Department of Biology, Indiana University-Purdue University Fort Wayne, USA
}

Copyright (C) 2015 by authors, all rights reserved. Authors agree that this article remains permanently open access under the terms of the Creative Commons Attribution License 4.0 International License

\begin{abstract}
Purple sea urchins and giant California sea cucumbers are becoming increasingly important sources of food and marine pharmaceuticals. Because there have been many fisheries established to harvest these species, many of them have been greatly depleted. In order to alleviate this problem intensive aquaculture is generating interest as a solution. However, when an animal is placed into an artificial system, there are a variety of stresses that it can encounter, such as salinity changes or handling. In order to determine which species is more susceptible to stress, various physiological and immunological assays were done on the coelomic fluid of purple sea urchins, Strongylocentrotus purpuratus and giant California sea cucumbers, Parastichopus californicus. Assays included total and phagocytic cell counts, phagocytic capacity, and lytic activity. Our results indicated that low salinity and handling both cause significant stress responses in sea urchins. For sea cucumbers, there were few significant differences from the control, and no differences in immune function. These results indicate that in an aquaculture environment the purple sea urchin is more likely to be stressed compared to the giant California sea cucumber, and that facilities interested in raising sea urchins should be particularly careful to avoid any condition that is potentially stressful.
\end{abstract}

Keywords Sea Urchin, Sea Cucumber, Comparative Immunity, Aquaculture, Stress

\section{Introduction}

Invertebrates such as sea urchins and sea cucumbers have been widely consumed throughout Asia for centuries and are of growing importance as a resource in the United States. They are both a source of high quality protein and of valuable pharmaceuticals, especially sea cucumbers which are being found to have a variety of anticancer and regenerative properties, as having many other valuable medical and pharmaceutical attributes [1]. Sea urchins have long been used as a research model, and as a food source are considered a delicacy $[2,3]$. Due to these various factors, the natural population has become the source of a growing fishery system [2]. However, as is commonly found in fisheries, as the demand increases, the natural population becomes overexploited, which leads to a population collapse, as has already happened in many of the sea urchin populations. This is not only a problem with sea urchins, as there is evidence that the giant California sea cucumber, Parastichopus californicus, will also soon undergo a population collapse $[4,5]$. Sea cucumber has recently become of great importance as an export from the United States to various countries, especially Japan; [6] it is essential that measures be taken to prevent overexploitation, while at the same time growing and maintaining the market. In order to prevent overexploitation, it is expedient to establish aquaculture facilities that can successfully raise these invertebrates for both research and consumption. One way is to establish inland intensive aquaculture facilities that avoid the problems associated with raising animals off of the coast, particularly loss to predation [7].

Though intensive aquaculture provides the clear benefits of preventing overexploitation of natural population and producing large amount of product, animals raised in this way are vulnerable to a variety of stressors [8]. These sources of stress include crowding, handling, and salinity and temperature fluctuations [9]. If an animal is stressed, the immune function decreases, leaving them vulnerable to disease, particularly viral and bacterial infections. There is currently no effective treatment for disease in echinoderms, as the use of antibiotics leads to the development of disease resistant bacteria, so any disease in the system can cause devastating losses [10]. Of the sources of stress listed above, two of them, handling and salinity fluctuations, were examined for their impact on the immune function of giant California sea cucumbers and purple sea urchins.

These particular stresses where selected as any animal in an intensive aquaculture system is routinely subjected to handling, and when used for research purposes also experiences handling for sampling purposes, such as the production of eggs or the collection of coelomic fluid. 
Systems that utilize salt water must be constantly monitored for salinity fluctuations, which can vary based on a variety of factors, especially daily evaporation. In addition, purchasing ocean water or salt water mixes is expensive, so if animals can be successfully raised in lower salinity than is natural to them, this will save the farm or research facility some significant expense. In aquaculture, a species that is resistant to stress is preferable, as it is easier to raise, more productive, and will have greater growth and survival rates. It is the goal of this study to compare the immune responses of these two species, in order to examine similarities and differences, and to make a recommendation for differences in conditions that these two species can be reared in.

\section{Materials and Methods}

\subsection{Experimental Design}

Purple sea urchins (Stronglyocentrotus purpuratus) and giant California sea cucumbers (Parastichopus californicus) where obtained from Bodega Marine Laboratory Station in Bodega Bay, CA and acclimated prior to the study. They were divided into three groups with two replicates within each group (a total of 6 animals per group); control group kept at the optimal salinity of $34 \mathrm{ppt}$ and never handled, kept at $34 \mathrm{ppt}$ and handled daily, and low salinity exposed group kept at $28 \mathrm{ppt}$ and never handled. Animals were handled three times daily for approximately 1 minute per animal at four hour intervals by netting or moving by hand for a total of 12 handling exposures. Temperature was maintained at $13^{\circ} \mathrm{C} \pm 1$ and sea urchins were fed kelp ad libitum, sea cucumbers were supplied with live sand (Nature's Ocean ${ }^{\circledR}$ BIO-ACTIV LIVE $^{\mathbb{B}}$ ARAGONITE). The conditions were maintained for 72 hours, and then the coelomic fluid from each individual sea urchin or sea cucumber was collected for analysis. Parameters for comparison were total and phagocytic coelomocyte count, phagocytic cell capacity, and lytic activity. These parameters were selected because in echinoderms, stress will induce an increase in cell number, particularly of the phagocytic cells. If this stress is ongoing, the ability of the phagocytic cells to function is impaired, resulting in lowered phagocytic activity and lytic activity [11, $12,13,14]$. Data analysis was done using Analysis of Variance (ANOVA) followed by post-Anova analysis of means using Tukey's Test. Beforehand, the Shapiro-Wilk's test of normality was also performed. The graphs include data presented with means \pm standard errors of the means.

\subsection{Total and Phagocytic Cell Count}

Cells obtained with an equal volume of anticoagulant were counted in $20 \mu \mathrm{l}$ aliquots via hemocytometer for total and phagocytic cell counts.

\subsection{Phagocytic Capacity}

To determine phagocytic capacity, for each individual, 50 $\mu \mathrm{l}$ of sample coelomic fluid with equal volume of anticoagulant was added in duplicate on Esco Fluro glass slides [15] and incubated at room temperature for 90 mins. After incubation, $50 \mu \mathrm{l}$ of formalin killed bacteria (Bacillus megaterium) was added and allowed to incubate for 60 mins. Slides were then carefully washed with PBS, and after air drying, fixed in methanol. After drying, slides were stained with Giemsa-Wright stain. Sea urchin and sea cucumber cells are easily visualized through microscopy, and least 50 coelomocytes were counted at 100x magnification per slide, and phagocytic capacity was determined by the percentage of coelomocytes containing 3 or more bacteria [11].

\subsection{Lytic Activity}

Coelomic fluid samples from each group of sea urchins were pooled to obtain adequate volume and assayed using a lysozyme turbidity assay. Sea cucumber coelomic fluid was not pooled. The coelomic fluid was allowed to separate for at least four hours, and then the serum was collected for the assay. The lysozyme turbidity assay was performed by making $0.05 \mathrm{M}$. sodium phosphate buffer, and adding 0.985 $\mathrm{g}$ of Micrococcus lysodeikticus powder to $4.925 \mathrm{ml}$ buffer, and added to $4.5 \mathrm{ml}$ of serum. Absorbance was read immediately in a spectrophotometer at $530 \mathrm{~nm}$ to give a 0 min reading, and readings were taken at 1 and 5 mins [16].

\section{Results}

\subsection{Total and Phagocytic Cell Count}

The total cell count (Fig. 1) for S. purpuratus showed a significant increase in the stress groups as compared to the controls, with both the salinity and handling exposed groups approaching $10 \times 10^{6}$ cells per ml, whereas the control total cell count is less than $5 \times 10^{6}$ cells per ml. For $P$. californicus (Fig. 2), however, there was only a significant increase in the handling group, with the total cell count approaching $10 \mathrm{x}$ $10^{6}$ cells per $\mathrm{ml}$, but there is no significant difference between the control group and the low salinity group, which both have total cell counts less than $5 \times 10^{6}$ cells per ml. The sea urchin phagocytic cell count showed a significant increase in the stress groups as compared to the control group (Fig. 3), with the control group at approximately $2 \times 10^{6}$ cells per $\mathrm{ml}$, the low salinity exposed group at approximately $5 \mathrm{x}$ $10^{6}$ cells per $\mathrm{ml}$, and the handling exposed group at approximately $7 \times 10^{6}$ cells per $\mathrm{ml}$. In contrast, the sea cucumber phagocytic cell count showed no significant differences between groups, with all below $2 \times 10^{6}$ cells per ml (Fig. 4). 


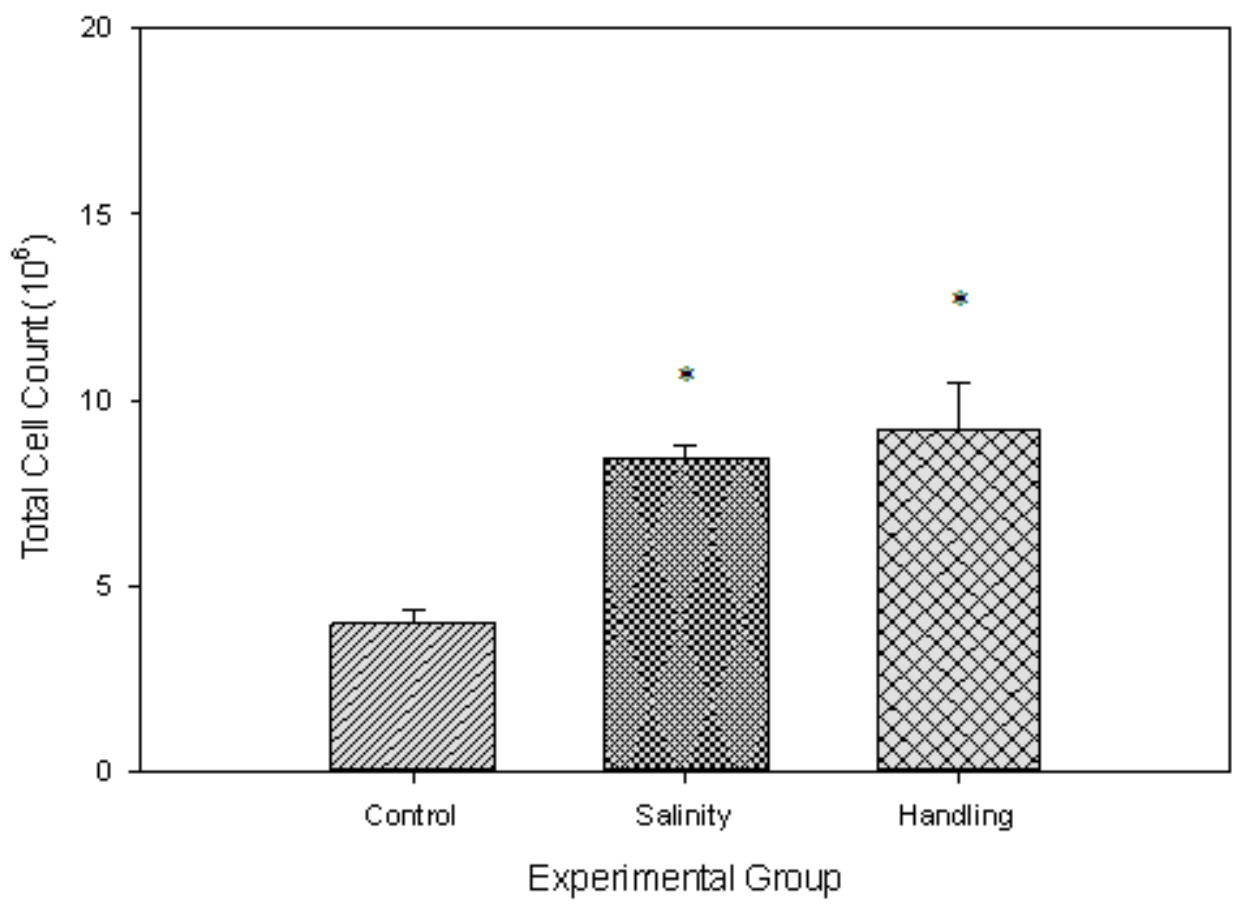

Figure 1. Sea urchin total cell count. * Significantly different $(\mathrm{P}<0.05)$.

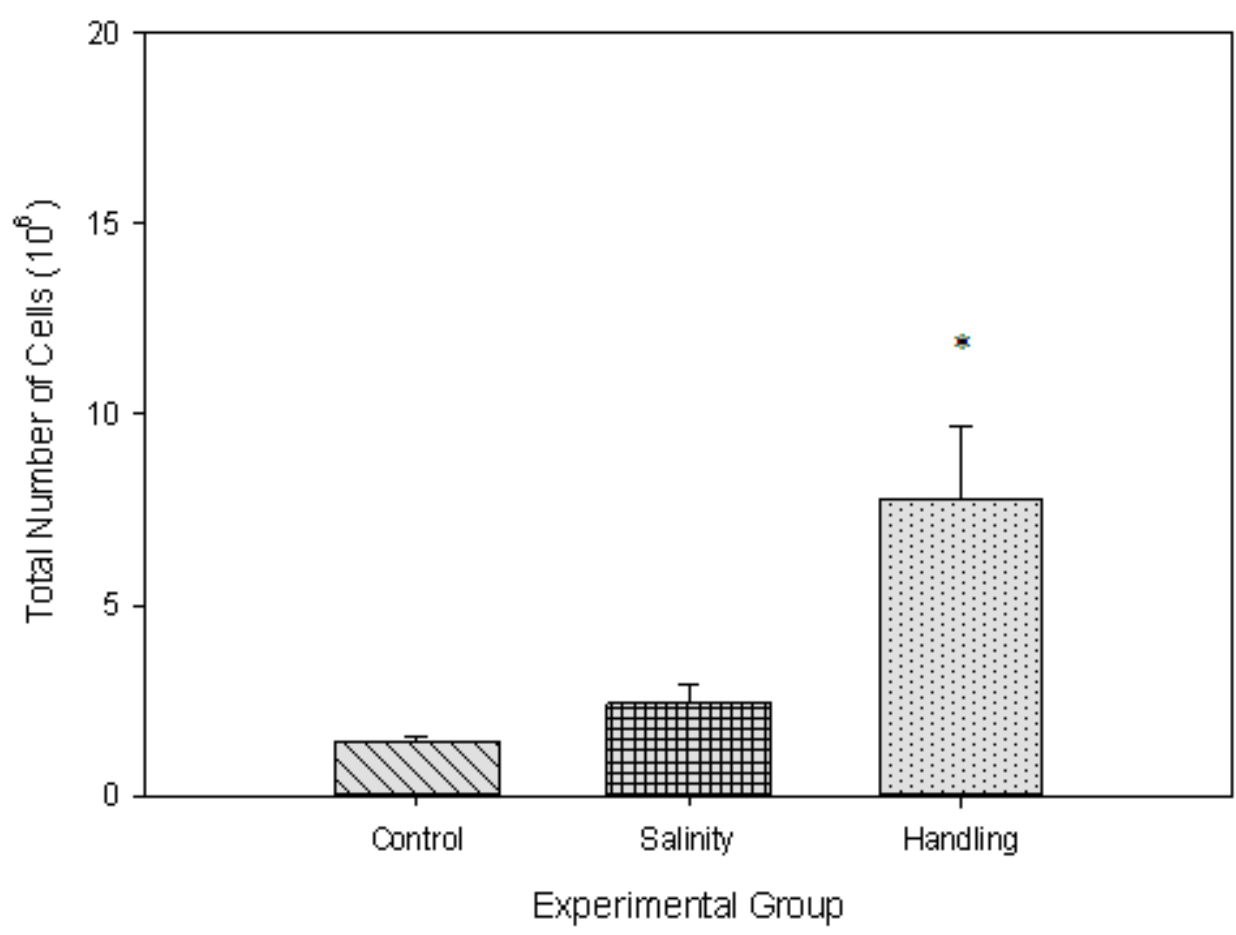

Figure 2. Sea cucumber total cell count. * Significantly different $(\mathrm{P}<0.05)$. 


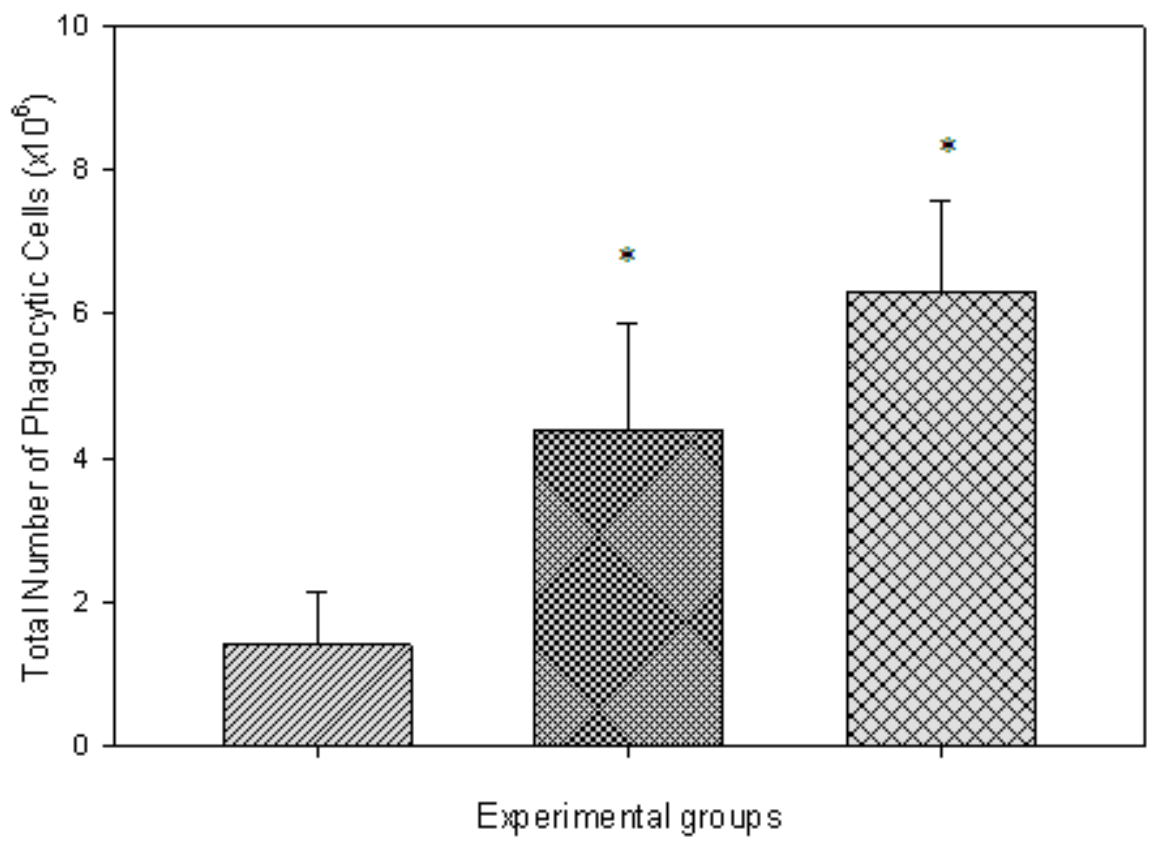

Figure 3. Sea urchin phagocytic cell count. * Significantly different $(\mathrm{P}<0.05)$.

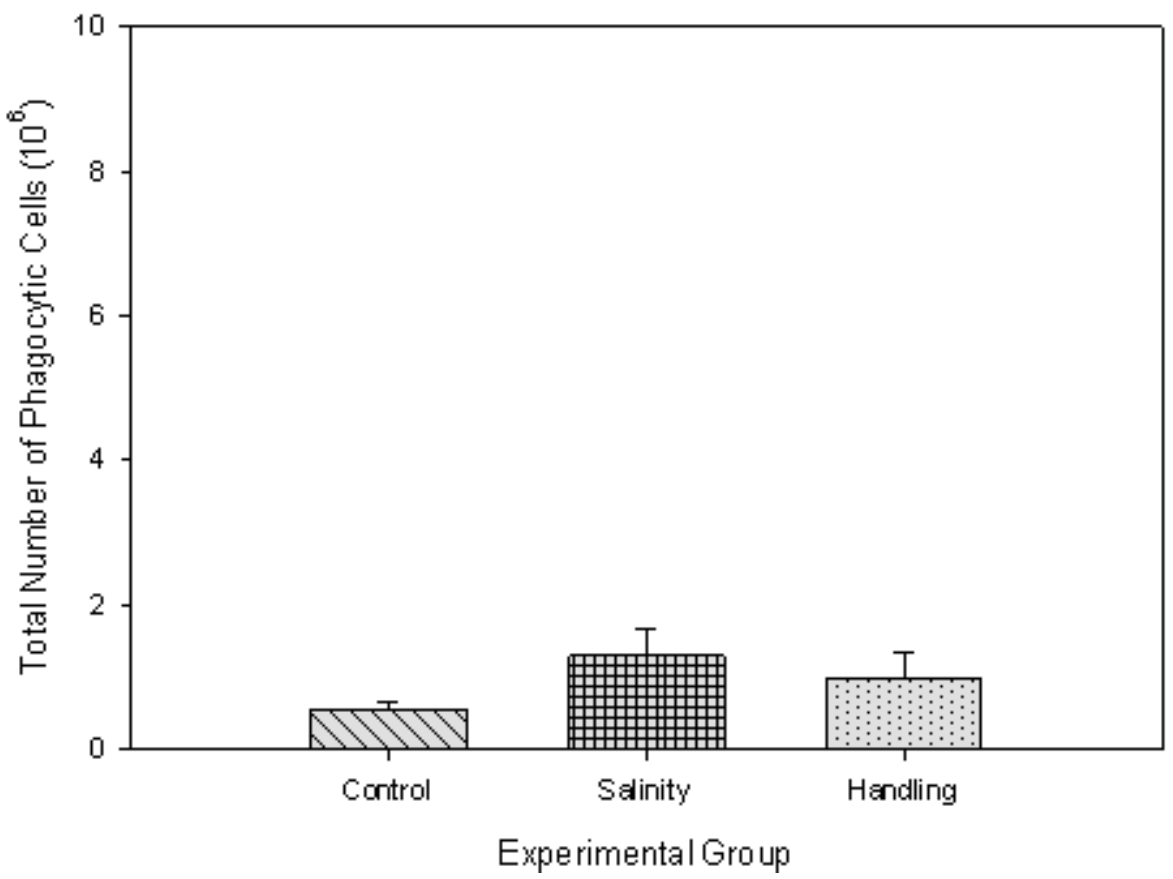

Figure 4. Sea cucumber phagocytic cell count. 


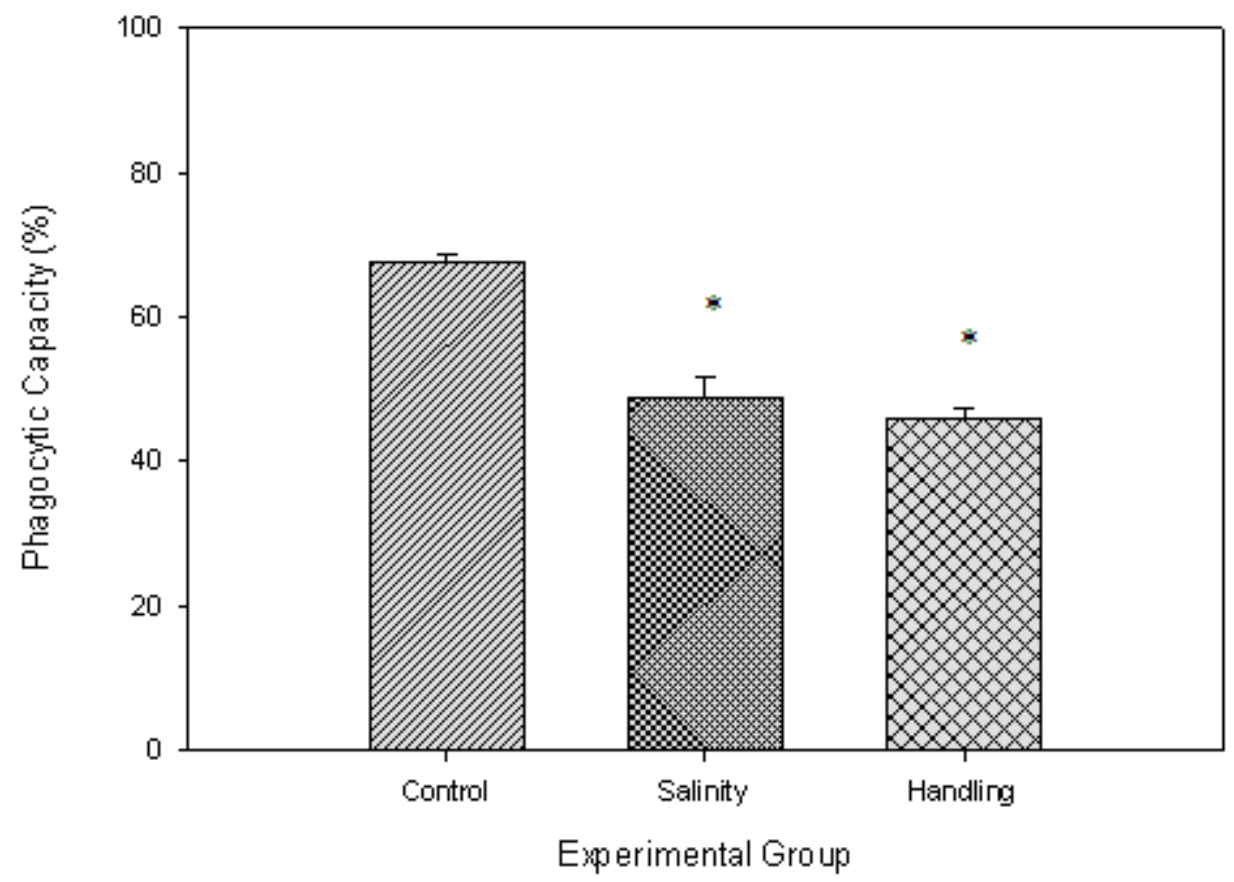

Figure 5. Sea urchin phagocytic capacity. * Significantly different $(\mathrm{P}<0.05)$.

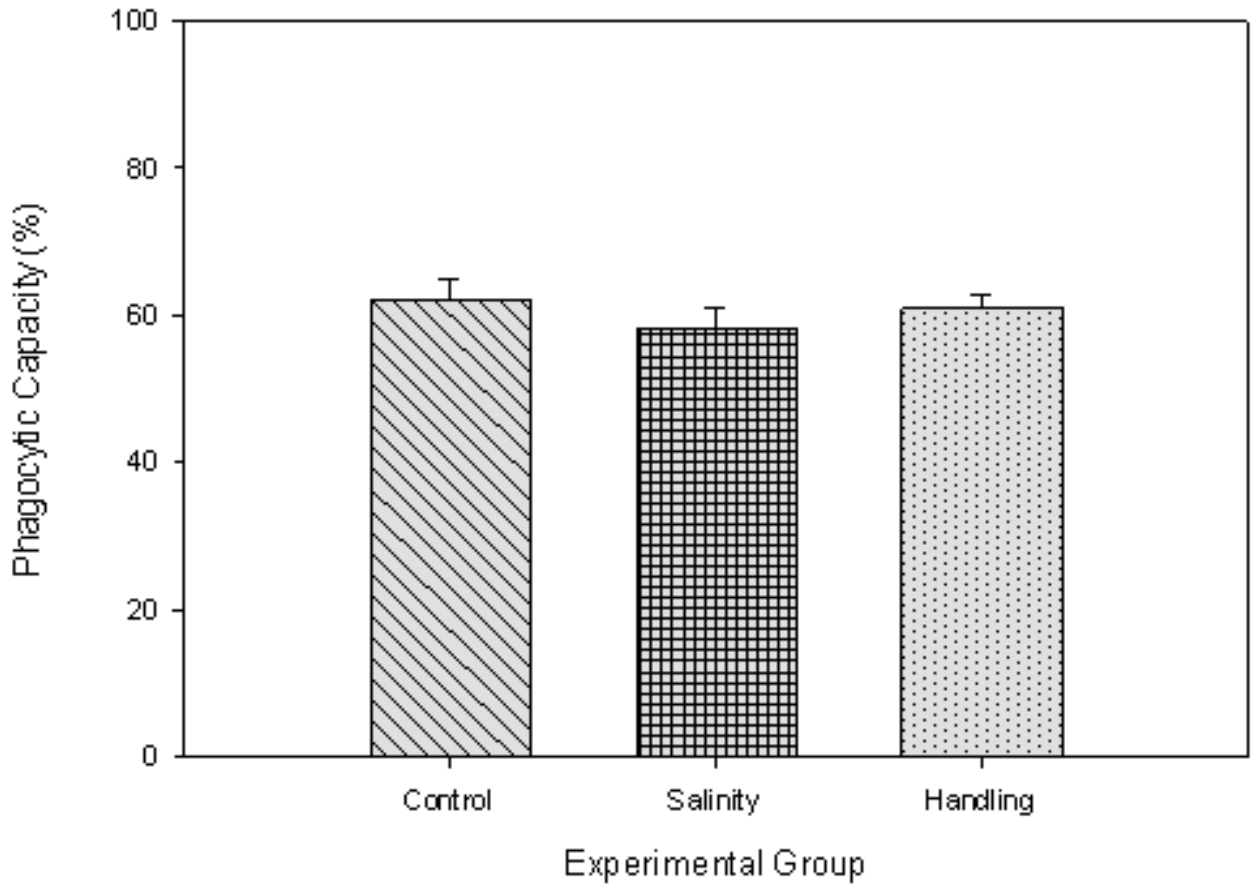

Figure 6. Sea cucumber phagocytic capacity.

\subsection{Phagocytic Capacity}

The sea urchin phagocytic capacity (ability of cells to successfully engulf three or more bacteria) [11] showed a significant decrease in the stress groups as compared to the control group, as there is approximately a $65 \%$ success rate in cells from the control rate, but approximately a 50\% success rate for cells sampled from both the low salinity exposed and handling exposed groups. (Fig. 5). The sea cucumber phagocytic capacity showed no significant differences, with all groups exhibiting an approximately $60 \%$ success rate (Fig. 6). 


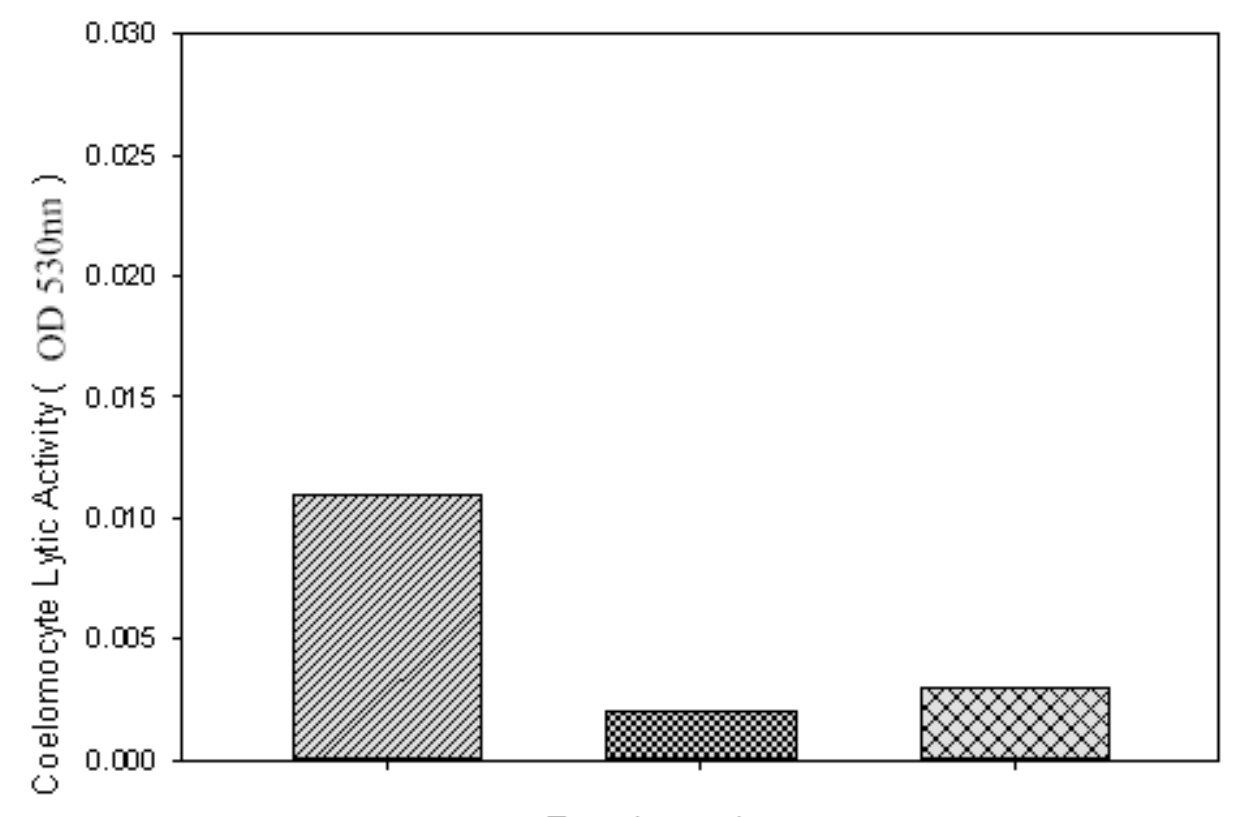

Experimental groups

Figure 7. Sea urchin lytic activity.

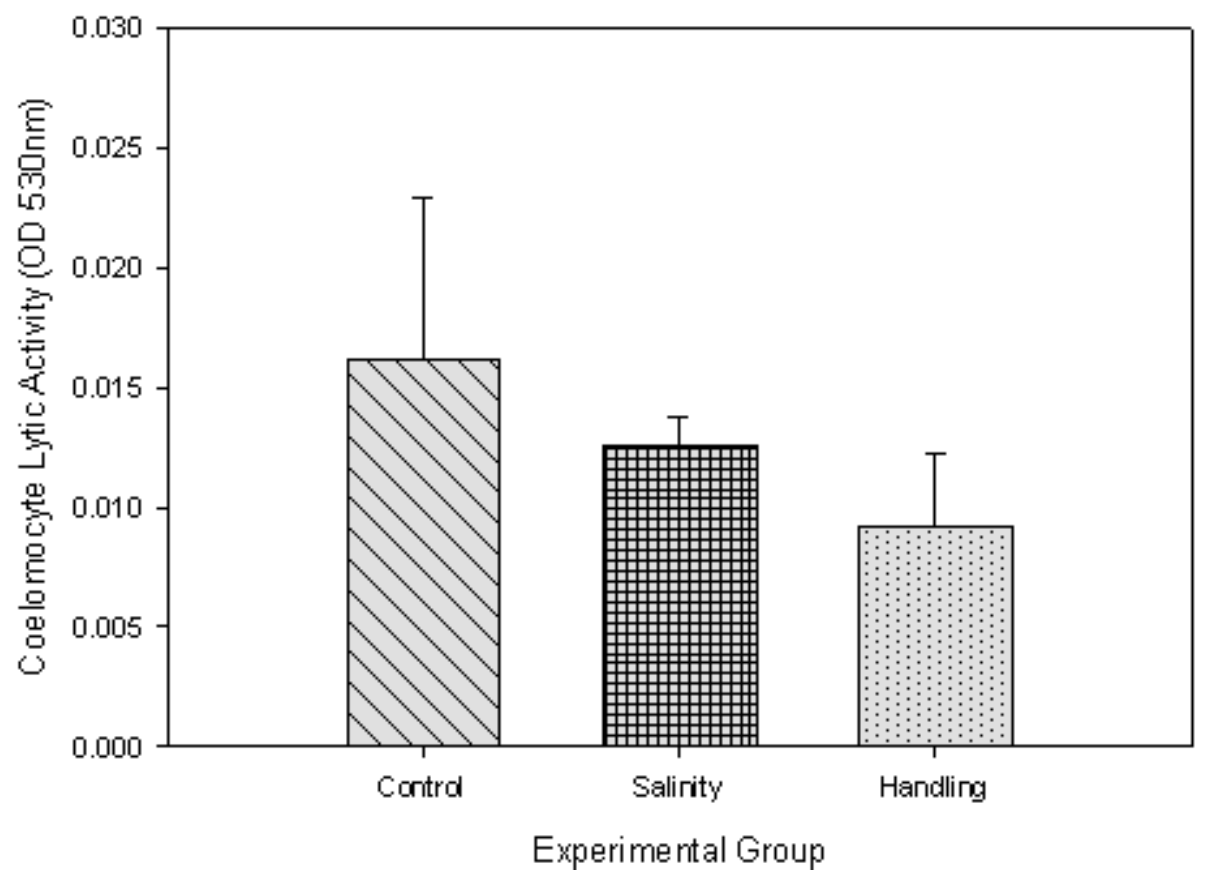

Figure 8. Sea cucumber lytic activity.

\subsection{Lytic Activity}

Though for sea urchins this result could not be statistically analyzed due to sample pooling, sea urchins in the stress groups appear to have a lower lytic activity than those in the control group (Fig. 7). Results for the sea cucumbers could be statistically analyzed due to greater obtained amounts of coelomic fluid per individual, and there is no significant difference in the lytic activity of the sea cucumbers (Fig. 8).

\section{Discussion}

In echinoderms that are under stress, certain types of cells will increase in order to maintain immunological function, and the increase or decrease observed is dependent on the type of stress [11-14, 16]. The results reported in Figure 1 and Figure 2 gives an initial indication that the sea urchins are experiencing stress and that the handling stress group of the sea cucumbers is experiencing some stress. In order to examine this more thoroughly, it is necessary to look at the different cell types. The only cell type that is directly comparable between the two species is the phagocytic cells, which are the primary immune effectors in both. In animals that are stressed, it is expected to observe an increase in this 
cell type, which is indeed the case for sea urchins (Fig. 3). For both the low salinity and the handling group, there is a significant increase $(\mathrm{P}<0.05)$ in phagocytic cell numbers, indicate that they are compensating immunologically for stress [16]. For the sea cucumbers however, there is no significant difference among groups (Fig. 4), and it is actually the salinity stress group that is showing a slight increase in phagocytic cell numbers, not the handling group. This suggests the increase in total cell count observed is not coming from the immune effector cells (phagocytic cells), which is confirmed by differential cell counts which are not presented here, which would suggest that the sea cucumbers are not being as greatly stressed as the sea urchins.

In order to confirm what appears to be indicated by the physiological results, the immunological results of the sea cucumbers and sea urchins were then examined. The first parameter is phagocytic capacity, which is a measure of the phagocytic cells' ability to engulf foreign particles. When an echinoderm is under stress, the phagocytic cells will increase to give immunological compensation, but if the stress in unrelieved, the ability of these cells to function will decrease [14]. This is indeed the case for sea urchins, in which the stress groups had a significantly lower phagocytic capacity than the control group (Fig. 5). However, for sea cucumbers, there is no significant difference $(\mathrm{P}>0.05)$ between groups (Fig. 6). It does appear that the control sea urchins have a slightly higher phagocytic capacity than the control sea cucumbers, and this is most likely due to interspecific differences.

Similar results were obtained for the lytic activity assays, the added The control groups for both sea urchins and sea cucumbers showed similar levels of lytic activity, but the stress groups are very different. For sea urchins, these groups appear to have a lower lytic activity (Fig. 7), but for sea cucumbers there is no significant difference $(\mathrm{P}>0.05)$ among groups (Fig. 8), though there appears to be a slightly lower lytic activity in the experimental groups. As lytic activity is stimulated by phagocytic activity, these results make them comparable with the phagocytic capacity results.

\section{Conclusions}

Based on the results obtained it appears that sea urchins are much more susceptible to experiencing stress and decreased immune function due to lowered salinity and handling than are sea cucumbers. This would indicate that systems that raise sea urchins should take particular care to maintain optimal salinity levels, and to keep handling to a minimum. Interestingly, though sea cucumbers did show some negative effects to lowered salinity and handling, none of them were significant. This could indicate a greater degree of resistance to salinity changes and handling, which would make them an ideal candidate for culturing. If these animals can be raised successfully at a lower than average salinity, it would reduce cost, while they also appear to be resistant to stress induced by handling. A follow up study could expose sea cucumbers to both conditions simultaneously to determine if the combined effect has a detrimental effect. Another area of focus for future research would be the effect of temperature fluctuations, which is a critical factor in aquaculture facilities. In addition, studies utilizing nutraceuticals as a means of reducing stress could be done to see if they have a positive effect on them immune function of echinoderms exposed to stressful conditions. Other studies would include comparisons of the quality of cultured sea cucumbers to wild-caught cucumbers, and longer term studies. Overall, the giant California sea cucumber appears to be an excellent candidate for intensive aquaculture, though more research is needed on its various biological needs [6].

\section{REFERENCES}

[1] P. L. Kiew, M. M. Don. Jewel of the seabed: sea cucumbers as nutritional and drug candidates, International Journal of Food Sciences and Nutrition, 63, 616-636, 2012.

[2] I. Bertocci, R. Dominguez, I. Machado, C. Freitas, J. Dominguez Godino, I. Sousa-Pinto, M. Goncalves, M. B. Gaspar. Multiple effects of harvesting on populations of the purple sea urchin Paracentrotus lividus in north Portugal, Fisheries Research, 150, 60-65, 2014.

[3] L. W. Botsford, A. Campbell, R. Miller. Biological reference points in the management of North American sea urchin fisheries, Canadian Journal of Fisheries and Aquatic Science, 61, 1325-1337, 2004.

[4] P. J. Betchtel, A. C. Oliveira, N. Demir, S. Smiley. Chemical composition of the giant red sea cucumber, Parastichopus californicus, commercially harvested in Alaska, Food Science and Nutrition, 1, 63-73, 2013.

[5] D. L. Paltzat, C. M. Pearce, P. A. Barnes, R. S. McKinley. Growth and production of California sea cucumbers (Parastichopus californicus Stimpson) co-cultured with suspended Pacific oysters (Crassostrea gigas Thunberg), Aquaculture, 275, 124-137, 2008.

[6] A. K. Azad, R. S. McKinley, I. P. Forster, C. M. Pearce. The California sea cucumber-A potential candidate for aquaculture, World Aquaculture, 45, 43-48, 2014.

[7] L. Hannah, C. M. Pearce, S. F. Cross. Growth and survival of California sea cucumbers (Parastichopus californicus) cultivated with sablefish (Anoplopoma fimbria) at an integrated multi-trophic aquaculture site, Aquaculture, 406-407, 34-42, 2013.

[8] J. D. Loy, C. Bartholomay, D. L. Harris, E. Scura, I. Kamrud. United States Patent, 2014. Patent No. 2 US 8,828,961 B2.

[9] F. Wang, H. Yang, F. Gao, G. Liu. Effects of acute temperature or salinity stress on the immune responses in sea cucumber, Apostichopus japonicas, Comparative Biochemistry and Physiology, Part A, 151, 491-498, 2008.

[10] D. V. Lightner, R. M. Redman. Shrimp diseases and current diagnostic methods, Aquaculture, 164, 201-220, 1998. 
[11] F-S. Chia, J. Xing. Echinoderm Coelomocytes (Review Article), Zoological Studies, 35, 231-254, 1996.

[12] P. S. Gross, W. Z. Al-Sharif, L. A. Clow, L. C. Smith. Echinoderm immunity and the evolution of the complement system, Developmental and Comparative Immunology, 23, 429-442, 1999.

[13] L. C. Smith, J.P. Rast, V. Brockton, D. P. Terwilliger, S. V. Nair, K. M. Buckley, A. J. Majeske. The sea urchin immune system. (Review Article), Invertebrate Survival Journal, 3, 25-39, 2006.

[14] L. D. Mydlarz, L. E. Jones, C. D. Harvell. Innate immunity, environmental drivers, and disease ecology of marine and freshwater invertebrates, Annual Review of Ecology,
Evolution, and Systematics. 37, 251-288, 2006.

[15] A. Mustafa, C. MacWilliams, N. Fernandez, K. Matchett, G. A. Conboy, Burka. "Effects of Sea Lice (Lepeophtheirussalmonis Kroyer, 1837) infestation on macrophage functions in Atlantic salmon (Salmosalar L.), Fish and Shellfish Immunology, 10, 47-59, 2000.

[16] A. E. Ellis. Lysozyme Assays,.J. S. Stolen, T.C. Fletcher, D. P. Anderson, B. S. Roberson, W. B. van Muiswinkel (Editors), Techniques in Fish Immunology. SOS Publications, Fair Haven, NJ USA, 1990.

[17] S. J. M. Hughes. Towards deep-sea toxicology: experimental approaches with echinoderms, University of Southampton, School of Ocean and Fish Sciences, PhD Thesis, 109-110, 2010. 